Teologia i Moralność, volumen 16(2021), numer 2(30)

doi: 10.14746/TIM.2021.30.2.10

ORCID: 0000-0002-9291-412X

KRZYSZTOF NIEWIADOMSKI

Wyższe Seminarium Duchowne Braci Mniejszych Kapucynów w Krakowie

\title{
Cnoty pokrewne sprawiedliwości w świetle etyki personalistycznej
}

\section{Wstęp}

Święty Tomasz z Akwinu opisuje cnoty, które nazywa pokrewnymi sprawiedliwości. Stanowią one część jego systemu aretologicznego. Wyjaśnia on, że w cnotach pokrewnych cnocie głównej zawiera się jakaś część wspólna z nią, ale także element różnicujący, przez który nie przysługuje im w całej pełni istotna treść cnoty głównej. Cnoty pokrewne sprawiedliwości usprawniają w oddawaniu bliźnim tego, co się im słusznie należy, ale nie mogą uzdolnić, by oddać dokładnie tyle, ile trzeba, ponieważ jest to niemożliwe (Tomasz z Akwinu 1970, q. 80, a. 1). W opinii autora artykułu cnoty te wskazują w szczególny sposób na cechy i uprawnienia osoby ludzkiej, przekraczające sprawiedliwość wymienną. Zadaniem, które postawił sobie autor artykułu, jest opisanie tych własności osoby ludzkiej (wskazywanych nie wprost przez cnoty pokrewne sprawiedliwości), uprawnień osobowych, które można dostrzec dzięki pracy wykonanej przez św. Tomasza, wykorzystanej jako baza do dalszej refleksji personalistycznej.

\section{Personalizm jako teoria i praktyka w odniesieniu do osoby ludzkiej}

Jak pisze hiszpański personalista Juan Manuel Burgos, Kościół potrzebuje dziś w sposób naglący antropologii, która jest zdolna nawiązać kontakt z myśleniem i doświadczeniem życiowym współczesnego człowieka, którego pojmowanie świata zmienia się $\mathrm{w}$ sposób niezwykle szybki i to w kierunku przeciwnym 
do chrześcijańskich kryteriów rozumowana. Można oczywiście odwoływać się do dawnych antropologii, takich jak tomizm. Burgos twierdzi jednak, że nie mogą one już zrealizować więcej, niż dokonały do tej pory. Porównuje on kierunki filozoficzne do ewangelicznych bukłaków. Nowe bukłaki może ofiarować współczesności personalizm (Burgos 2012, 355-356).

Juan M. Burgos przypomina, że Kościół obszernie skorzystał z antropologii personalistycznej przy opracowywaniu dokumentów Soboru Watykańskiego II. Hiszpański personalista słusznie jednak postuluje, by uczynić dużo szerszy i głębszy użytek z tej filozofii. Dopóki to się nie stanie, marnotrawi się ważną część niezwykle bogatego dorobku znaczącej grupy filozofów chrześcijańskich XX w. i w konsekwencji nie powstrzymuje się kryzysu filozoficznego i kulturowego zwłaszcza w odniesieniu do chrześcijan świeckich - nie dając im do użytku głębokiego, aktualnego, systematycznego instrumentu, który dopomógłby im zrozumieć samych siebie i świat (Burgos 2012, 356).

Edukacja współczesnego człowieka mocno naznaczona jest paradygmatem nauk doświadczalnych, jak również wrażliwością na prawa osoby. Dlatego szczególnie cenne wydaje się to, że personalizm daje możliwość połączenia danych filozofii, nauk humanistycznych i empirycznych oraz teologii w jedną całość. W celu stworzenia takiego spójnego systemu nie można ignorować wyników badań współczesnych nauk antropologicznych, ale też bogatego doświadczenia osoby, w tym doświadczenia moralnego. Zarówno jedno, jak i drugie, kształtuje bowiem świadomość współczesnego człowieka. Wartością personalizmu jest także to, że jawi się on nie tylko jako teoria, lecz także jako systemem praktyczny, mający bezpośrednie odniesienie do rzeczywistości (Guzowski i Kosche 2016, 72-73).

Personalizm nie przyjął struktury ani od tomizmu, ani też od żadnej innej filozofii, ale wypracował własną metodologię i pojęcia, biorąc początek od francuskiego filozofa Emmanuela Mouniera (Burgos 2012, 347-348). Juan M. Burgos charakteryzuje ten nurt w sześciu punktach. Po pierwsze, personalizm wskazuje na fundamentalną różnicę między rzeczami i osobami oraz konieczność stosowania wobec tych ostatnich własnych kategorii filozoficznych. Pod wpływem greckiej metafizyki filozofia zachodnia, także scholastyka katolicka, ulegała tendencji do wypracowania pojęć antropologicznych, opierając się na refleksji o rzeczach lub zwierzętach, aby później zastosować je do człowieka. W wyniku takiego ujęcia to, co specyficznie ludzkie, nie zostało wystarczająco wydobyte. Jednak nawet w tych wymiarach, w których człowiek i inne byty mogą wydawać się podobne - takich jak wymiar fizyczny czy zmysłowy - różnią się one głęboko. Z tego powodu potrzeba personalizmowi własnych i wyłącznych kategorii filozoficznych, które należy tworzyć, wychodząc od analizy filozoficzno-eksperymentalnej o charakterze fenomenologicznym. Po drugie, filozofia personalistyczna wskazuje na autonomiczny, źródłowy i strukturalny charakter uczuciowości. Filozofowie, tacy jak Max Scheler czy Dietrich von Hildebrand, wyrażają pogląd, że uczuciowość 
stanowi istotną, źródłową i autonomiczną strukturę, trzecią kolumnę struktury człowieka, obok poznania i woli. Po trzecie, personaliści uznają za ważne relacje międzyosobowe. Personalizm w pełni przejął w tej materii dorobek filozofii dialogu. Relacja, ostatnia z przypadłości dla Arystotelesa, przyjmuje tu charakter istotowy. Podkreśla się bowiem, że człowiek rozwija się tylko w relacji z drugim człowiekiem. Najbardziej radykalnie sformułował ten postulat Emmanuel Lévinas, wypracowując quasi-metafizykę dialogiczną świata: dialog poprzedza bycie i dlatego etyka znajduje się przed metafizyką i ontologią (Burgos 2012, 348-349).

Po czwarte, personalizm występuje przeciw intelektualizmowi. Inteligencja stanowi rzeczywistość fundamentalną w życiu człowieka, jednak według personalizmu ponad poznaniem stoją wartości moralne i religijne, wolność i „serce”, od których zależą decyzje moralne i zdolność miłości. Zbytnie podkreślenie znaczenia inteligencji prowadzi do zamknięcia się w czynnościach badania procesów poznawczych i odstawienia na plan dalszy ludzkiej praxis. Personalizm jest ukierunkowany na badanie wielorakich wymiarów, w których rozwija się ludzkie działanie. Owocem takiego ujęcia jest podjęcie przezeń tematów miłości, pracy, twórczości estetycznej czy zagadnień filozofii społecznej i politycznej (Burgos 2012, 349).

Po piąte, personaliści postrzegają jako ważne dane dla swojej refleksji cielesność i płciowość osoby. Personalistyczne spojrzenie na osobę jest całościowe, zaś fenomenologiczne ujęcie ciała ludzkiego pozwala odkryć bogactwo znaczeń wszystkich aspektów cielesności. Cielesność otwiera drogę ku ujęciu zagadnień płciowości (co widać np. w pracach Karola Wojtyły), kobiecości, małżeństwa i rodziny (Burgos 2012, 349-350). Wreszcie po szóste, personalizm afirmuje wymiar wspólnotowy, nie gubiąc centralnego miejsca osoby jako podmiotu społecznego. Afirmując jednostkę, ukazuje ją zawsze w relacjach z innymi. Pozwala znaleźć złoty środek pomiędzy skrajnościami liberalnego indywidualizmu i kolektywizmu (Burgos 2012, 350).

Akwinata uznaje wartość osoby ludzkiej, stąd niektórzy autorzy uznają go za personalistę w szerokim znaczeniu tego terminu, nie jest to jednak powszechne. Nie jest on na pewno reprezentantem personalizmu w zaznaczeniu ścisłym, czyli filozofii zbudowanej wokół pojęcia osoby (Burgos 2010, 155-156). Jego opis człowieka jest jednak doskonałą podstawą dla dalszej refleksji, także na polu personalizmu. Święty Tomasz, opisując wymiar moralny osoby i twórczo korzystając z dorobku bogatej tradycji aretologicznej, opisuje cnoty, które wykraczają poza sprawiedliwość. Ukazuje w ten sposób godność człowieka, nie rozwija jednak tego zagadnienia. Cnoty pokrewne sprawiedliwości można pogrupować według kryteriów personalistycznych, innych niż podał św. Tomasz. Autor artykułu wykorzystuje w tym celu kategorię relacji międzyosobowej. 


\section{Cnoty określające postawy afiliacyjne wobec osób znaczących i ob- darzonych autorytetem}

Jako pierwszą cnotę pokrewną sprawiedliwości św. Tomasz wymienia pietas, co Feliks Wojciech Bednarski przełożył na język polski jako „pietyzm”. Jest to cnota usprawniająca okazywanie czci rodzicom oraz patriotyzm (Tomasz z Akwinu 1972, q. 101). Akwinata pisze, że po Bogu największą wdzięczność człowiek jest winny rodzicom i ojczyźnie (Tomasz z Akwinu 1972, q. 101, a. 1). Dzięki rodzicom otrzymuje on życie i inne ważne dobra, dzięki ojczyźnie - wychowanie, przestrzeń wzrostu. Cześć należna rodzicom powinna objąć również i innych krewnych ze względu na pochodzenie od wspólnych przodków, jak to podkreśla św. Tomasz za Arystotelesem (Arystoteles 1996, 254).

Ponieważ zadaniem sprawiedliwości jest oddawanie ludziom tego, co im się słusznie należy, gdzie istnieje odrębna podstawa prawna należności, tam jest miejsce na odrębną cnotę. Otóż w pietyzmie taką odrębną podstawą należności jest to, że pewne osoby stanowią źródło bytu lub władzy (Tomasz z Akwinu 1972, q. 101, a. 3). Nie sposób jednak oddać rodzicom i ojczyźnie dokładnie tyle, na ile zasługują. Rodzice mają prawo do czci jako źródło bytu swojego potomstwa - aby dzieci opiekowały się nimi w razie choroby, pomagały im, jeśli cierpią niedostatek oraz wykazywały w stosunku do matki i ojca należne posłuszeństwo i szacunek. Dla części ludzi okazywanie im szacunku oznacza pamięć o nich, odwiedziny itp. Święty Tomasz twierdzi, że osoby związane węzłami pokrewieństwa lub miłości ojczyzny należy otaczać czcią i świadczyć im pewne powinności, ale nie wszystkim w równej mierze, przede wszystkim należy się to rodzicom, innym zaś w miarę własnych możliwości i ich praw.

Nie jest także łatwo wystarczająco wynagrodzić cnotę i dlatego ze sprawiedliwością łączy się szacunek (observantia) - cnota, dzięki której ludzie otaczają czcią tych, którzy piastują jakąś godność (Tomasz z Akwinu 1970, q. 102, a. 1). Święty Tomasz porównuje władzę różnych osób do władzy ojcowskiej: „Osoba piastująca jakąś godność jest jakby ośrodkiem zarządzania w pewnych sprawach, np. naczelnik państwa w sprawach obywatelskich, dowódca w sprawach odnoszących się do wojny, nauczyciel w sprawach nauki itp. Wszystkie tego rodzaju osoby zwane są «ojcami», gdyż ich troski są podobne do ojcowskich” (Tomasz z Akwinu 1970, q. 102, a. 1). Jak zaznacza św. Tomasz, istnieją dwa rodzaje obowiązków: prawne, których spełniania żądają ustawy, i do takich właśnie zalicza się powinność okazywania szacunku tym, którzy z tytułu swego urzędu są przełożonymi, oraz moralne, których spełnienia wymaga poczucie uczciwości. Tego właśnie rodzaju obowiązkiem jest okazywanie poważania również i tym, którzy piastują jakąś godność, ale nie są własnymi przełożonymi (Tomasz z Akwinu 1970, q. 102, ad. 2).

Kolejną rozważaną cnotą jest cześć, czyli dulia (Tomasz z Akwinu 1972, q. 103). Usprawnia ona akty czci należne osobie dla jej wybitnych zalet. Cześć dla 
Osoby Boga może polegać na samych tylko aktach wewnętrznych, natomiast wobec ludzi może być wyrażona jedynie przez znaki zewnętrzne, a więc albo przez słowa, albo przez czyny, jak np. ukłon, oddanie pierwszeństwa w przejściu itp. (Tomasz z Akwinu 1972, q. 103, a. 1). Akwinata odróżnia poważanie od czci. Poważanie $\mathrm{z}$ jednej strony jest pobudką do okazywania czci, z drugiej zaś strony jest jej celem (Tomasz z Akwinu 1972, q. 103, a. 1, ad. 1). Od czci różni się też pochwała. Wyraża się przy pomocy samych słów, cześć zaś okazuje się także zewnętrznymi znakami. Ponadto, oddając cześć, składa się świadectwo o przymiotach danej osoby, natomiast chwaląc kogoś - o jego dobroci ze względu na pewien cel. Chwała natomiast jest wynikiem czci i pochwały, jest uznaniem sławnej osoby (Tomasz z Akwinu 1972, q. 103, a. 1, ad. 3). Cześć zawsze należy się komuś z powodu jego wybitnego znaczenia lub wyższości, nie wynika z tego jednak, by ten, kogo się czci, był bardziej wybitny od człowieka, który mu tę cześć okazuje. Wystarczy, że jest tak pod pewnym względem lub że jest bardziej wybitny niż niektórzy inni ludzie (Tomasz z Akwinu 1972, q. 103, a. 2). W każdym człowieku można znaleźć coś, czym przewyższa innego, w myśl słów Apostoła: „w pokorze uważajcie jedni drugich za wyższych od siebie" (Flp 2,3). Zgodnie z tym poleceniem wszyscy ludzie winni uprzedzać się wzajemnie we czci (Tomasz z Akwinu 1972, q. 103, a. 2, ad. 3).

Następna cnota pokrewna sprawiedliwości to posłuszeństwo (obedientia). Posłuszeństwo pochodzi z szacunku, który polega na czci i poważaniu przełożonego. $\mathrm{Z}$ tego powodu mieści się $\mathrm{w}$ różnych cnotach pokrewnych sprawiedliwości, mimo że samo w sobie jest cnotą odrębną, o właściwym sobie przedmiocie, którym jest spełnianie rozkazów. Gdy posłuszeństwo wynika z poważania przełożonych, należy do cnoty karności, gdy pochodzi z poważania rodziców, zawiera się w pietyzmie, gdy pochodzi z czci Bożej, mieści się w cnocie religijności jako przejaw pobożności (Tomasz z Akwinu 1972, q. 104, a. 3, ad. 1). Przy tym szacunek odnosi się wprost do wybitnej osoby i dlatego zawiera w sobie tyle odrębnych gatunków posłuszeństwa, ile jest odrębnych racji wybitności danego człowieka. Natomiast posłuszeństwo odnosi się do polecenia przełożonego, a więc wypływa tylko z jednego powodu. Ponieważ jednak szacunek dla przełożonego wymaga posłuszeństwa wobec jego poleceń - wszelkie posłuszeństwo zachowuje swą jedność gatunkową, chociaż pochodzi z gatunkowo różnych przyczyn (Tomasz z Akwinu 1972, q. 104, a. 2, ad. 4).

Analizując powyższe cnoty w optyce personalistycznej, należy podkreślić, że przez dobre wypełnianie swojego powołania osoba ludzka zasługuje na cześć, szacunek i posłuszeństwo, mimo że spełnia tym samym swoje obowiązki. Należy się jej za to uznanie, docenienie jej zaangażowania i starań. Dotyczy to także wspólnoty osób rozciągniętej w czasie i przestrzeni - ojczyzny. Taki wniosek potwierdza doświadczenie etyczne opisane przez starożytnych filozofów, twórczo wykorzystane przez św. Tomasza, który odnosi się w opisie cnót pokrewnych 
sprawiedliwości do Arystotelesa, Cycerona, Seneki i ojców Kościoła. Postawa przeciwna byłaby instrumentalnym traktowaniem osób mających do wykonania jakieś zadanie wobec innych: rodziców czy osób pełniących służbę publiczną. Osobie należy się cześć także za pracę nad sobą, za wypracowanie cnót, które przecież następnie ułatwiają relacje międzyosobowe, budują dobro w przestrzeni międzyosobowej. Te wnioski wskazują na osobę jako kogoś realizującego się poprzez działanie, stającą się przez swoje akty piękną i dobrą, godną podziwu.

Kolejna konkluzja, która narzuca się w obrębie przyjętej metodologii personalistycznej, to nieporównywalna z innymi bytami wartość człowieka, a co za tym idzie nieporównywalna z niczym wartość jego aktów moralnych. Cnoty, które mobilizują do odpłaty za otrzymane dobro, za zaangażowanie wniesione do wspólnoty, nie mogą zmieścić się w prostej sprawiedliwości, ponieważ człowiek niejednokrotnie nie jest w stanie odpłacić w sposób równowartościowy za to wszystko, co otrzymał. Nie da się raz na zawsze podziękować rodzicom i spłacić swojego długu wobec nich. Nie można instrumentalnie potraktować rodzica i zerwać z nim relacji po wypełnieniu jego zadania i wyprowadzeniu się z domu. Osoba nie może być nigdy traktowana jako instrument do jakiegoś celu, społecznego czy osobistego. Okazuje się, że próba wyrównania raz na zawsze jakiegoś rachunku za otrzymane dobrodziejstwo może być w konsekwencji depersonalizacją bliźniego.

Osobie wybitnej w jakiejś dziedzinie należy się uznanie dla jej osiągnięć, cześć. Jest to cześć dla wartości, które ona reprezentuje, ale i pochwała dla niej samej, ponieważ potrafiła je wcielić w swoje życie. Nie można pozostawać wobec człowieka obojętnym. Jedynym właściwym odniesieniem do niego jest miłość (Wojtyła 1986, 43). Miłość wyraża się także w nawiązaniu relacji, w posłuszeństwie i wdzięczności. Pietyzm, szacunek, cześć i posłuszeństwo rozwijają osobę, która je praktykuje. Sama sprawiedliwość wymienna nie byłaby budowaniem relacji, ale korzystaniem tylko z własnych praw i należności. Cnoty pokrewne sprawiedliwości pomagają zrealizować w całej głębi relację międzyosobową i uniknąć pokusy utylitaryzmu.

Opisane powyżej cnoty wskazują na wdzięczność w relacjach nierównorzędnych, są ukierunkowane na szacunek dla osoby ze względu na jej wyższą, pod jakimś względem, pozycję. Jednak oprócz tego typu odniesień istnieją także relacje równorzędne. Także one wymagają pogłębionej analizy z punktu widzenia personalizmu.

\section{Cnoty budujące relacje równorzędne}

Ważną cnotą obejmującą akty afirmacji osoby jest wdzięczność (gratitudine). Obejmuje ona akty, które mogą być spełniane wobec rodziców czy przełożonych, ale nie wiążą się istotowo z ich wyższą pozycją, do której odnosi się cnota piety- 
zmu, szacunku, czci lub posłuszeństwa. Święty Tomasz pisze, że wobec dobroczyńców istnieją szczególne zobowiązania, nie tak duże jednak jak wobec Boga, rodziców i przełożonych (Tomasz z Akwinu 1972, q. 106, a. 1). Daje on dalsze wskazówki: im większy jest otrzymany dar, tym większa winna być wdzięczność. Po drugie, dar jest tym większy, im bardziej jest bezinteresowny (Tomasz z Akwinu 1972, q. 106, a. 2). Pod względem uczucia wdzięczność powinna być natychmiastowa. Jeśli zaś chodzi o odpłatę, należy zaczekać do odpowiedniej pory, jak bowiem słusznie zauważa cytowany przez Akwinatę Seneka: „Kto nadmiernie pragnie uiścić się z daru, ten nie chce być dłużnikiem. Kto zaś nie chce być dłużny, ten jest niewdzięczny" (Seneka 1965, 278).

Analizując tę cnotę w optyce personalistycznej, trzeba zauważyć, że wdzięczność zawsze zmierza do tego, aby w miarę możności wyświadczyć dobroczyńcy więcej, niż się otrzymało. Jeśli zaś ktoś nie może się odwdzięczyć, wystarczy, by miał taką wolę (Tomasz z Akwinu 1972, q. 106, a. 6, ad. 1). Święty Tomasz twierdzi, że można mówić o obowiązku odwdzięczenia się, który pochodzi z miłości, która im więcej daje, tym większe rodzi zobowiązanie, w myśl słów Pawła: „Nikomu nie bądźcie nic dłużni poza wzajemną miłością” (Rz 13,8). Nic więc nie szkodzi, jeśli obowiązek wdzięczności nie ma kresu, wskazuje Akwinata (Tomasz z Akwinu 1972, q. 106, a. 6, ad. 2). Sprawiedliwość, będąca cnotą główną, bierze pod uwagę pewną równość rzeczy, natomiast wdzięczność - równość woli, w tym znaczeniu, by tak jak dobroczyńca, dzięki chętnemu nastawieniu woli uczynił chętnie to, do czego nie był zobligowany, tak ten, kto doznał dobrodziejstwa, odwzajemnił się w większym stopniu, niż jest do tego zobowiązany (Tomasz z Akwinu 1972, q. 106, a. 6, ad. 3).

Kolejnym zagadnieniem poruszanym przez Akwinatę jest cnota prawdomówności (veritas). Prawdomówność jest cnotą, gdyż przekaz prawdy jest czynnością dobrą, a cnota jest sprawnością, która czyni dobrym tego, kto ją posiada i sprawia, że jego działanie jest dobre (Tomasz z Akwinu 1972, q. 109, a. 1). Prawdomówność stanowi złoty środek, usprawniając człowieka, by mówił prawdę, kiedy należy i w odpowiedni sposób (Tomasz z Akwinu 1972, q. 109, a. 1, ad. 3).

Prawdomówność ma dwie cechy wspólne ze sprawiedliwością: po pierwsze, dotyczy innych, którym wyjawia swoją wiedzę. Po drugie, podobnie jak sprawiedliwość, także prawdomówność polega na pewnej równości wprowadzonej między znakiem a rzeczywistością przez ten znak wyrażoną. Różni się jednak od sprawiedliwości naturą powinności. Prawdomówność bowiem odnosi się nie do należności opartej na prawie, lecz raczej do należności moralnej, ze względu na to, że człowiek na podstawie samej uczciwości winien drugiemu ujawniać prawdę. Tak więc prawdomówność jest częścią sprawiedliwości w tym znaczeniu, że łączy się z nią jako cnota drugorzędna z cnotą główną (Tomasz z Akwinu 1972, q. 109, a. 1, ad. 3). Cnota prawdomówności ma ogromne znaczenie dla relacji międzyosobowych. Prawda i prawdomówność jest wyrazem szacunku wobec 
osoby, „należą się” osobie. Nieprawda umożliwia manipulację. Kłamstwo uprzedmiotawia osobę, jest oparte na założeniu, że nie ma ona prawa do decyzji opartych na prawdzie. Tylko na prawdzie można zbudować trwałe relacje międzyludzkie.

Według Akwinaty istnieją jeszcze inne należności wobec osoby, a mianowicie takie, które są niezbędne do spotęgowania piękna cnoty, ale nie są konieczne do postępowania godziwego. Do tego rodzaju należności odnosi się uprzejmość czy przyjacielskość oraz hojność (Tomasz z Akwinu 1970, q. 80, a. 1). Można zauważyć istnienie dwojakiej przyjaźni. Jedna polega na wzajemnej miłości, druga zaś na zewnętrznym okazywaniu znakami (słowami i czynami) tego, co się innym ludziom należy, choćby ludzie ci byli nieznani i obcy. Nie jest to przyjaźń w pełnym znaczeniu tego słowa, ale tylko pewne jej podobieństwo ze względu na to, że człowiek w obcowaniu z innymi odnosi się do nich w sposób przyjazny. Nie oznacza udawania, gdyż nie okazuje się znaków przyjaźni doskonałej jak wobec osób związanych węzłem szczególnej przyjaźni (Tomasz z Akwinu 1972, q. 114, a. 1, ad. 1-2). Przyjaźń, przyjacielskość (amicitia) w znaczeniu uprzejmości (affabilitas), jako pewien wyraz miłości należy się każdej osobie - otwartość na nią, życzliwość. Jedną z cech charakterystycznych personalizmu jest relacyjność, którą trudno pomyśleć bez otwartości i uprzejmości. Doświadczenie ukazuje tę cnotę jako niezbędną w społeczeństwie. Święty Tomasz argumentuje jej użyteczność „wymaganiami porządku”, aby stosunki między ludźmi w ich towarzyskim współżyciu układały się w sposób właściwy, zarówno co do słów, jak i co do czynów, tak mianowicie, aby każdy człowiek odnosił się do innego człowieka tak, jak się należy (Tomasz z Akwinu 1972, q. 114, a. 1).

Cnota przyjaźni jest częścią sprawiedliwości, wiążąc się z nią jako z cnotą główną. Podobnie jak sprawiedliwość dotyczy ona innych ludzi. Nie jest jednak pełną sprawiedliwością, gdyż jej podstawą nie jest należność w pełnym tego słowa znaczeniu, nakładająca obowiązek oddania komuś tego, co mu się należy z tytułu prawa albo na mocy otrzymanego dobrodziejstwa. Opiera się tylko na powinności wynikającej z ,pewnej uczciwości” (podobnie jak prawdomówność) i będącej raczej zobowiązaniem wobec siebie samego niż wobec innych, by postępować wobec nich tak jak przystoi (Tomasz z Akwinu 1972, q. 114, a. 2). Wydaje się, że św. Tomasz zbyt mało dowartościowuje tę cnotę, skupiając się jedynie na uczciwości skoncentrowanej na sobie samym, nie rozwijając kontekstu godności osoby bliźniego i związanych z nią uprawnień, konieczności budowania relacji międzyludzkich czy uzyskania przestrzeni we wspólnocie potrzebnej do życia każdemu człowiekowi, co podkreśla personalizm.

Cnotą, która reguluje właściwe użycie dóbr materialnych, wskazującą na prymat osoby nad pieniądzem, jest hojność (liberalitas). Według Akwinaty zróżnicowanie gatunkowe czynności pochodzi od przedmiotu, którym w wypadku hojności są pieniądze lub rzeczy wartościowe. Każda cnota jest właściwym stosunkiem do swego przedmiotu, stąd hojność odnosi się do użytkowania pieniędzy i majątku 
(Tomasz z Akwinu 1972, q. 117, a. 3). Jak zauważa dominikański teolog, w przeciwieństwie do sprawiedliwości hojność nie dotyczy obowiązku wynikającego z prawa, ale z obowiązku moralnego, którego podstawą jest godziwość, a nie zobowiązanie względem drugiej osoby. $Z$ tego względu cecha powinności występuje w tej cnocie w niewielkim stopniu (Tomasz z Akwinu 1972, q. 117, a. 5, ad. 1). Dar człowieka miłosiernego ma swe źródło w pewnym nastawieniu uczucia człowieka obdarowującego w stosunku do obdarowanego. Dlatego taki dar jest owocem miłości lub przyjaźni. Natomiast dar pochodzący z hojności wynika z pewnego nastawienia do pieniędzy, których człowiek hojny nie pożąda ani nie kocha, a więc chętnie ich udziela nie tylko przyjaciołom, ale także nieznajomym, kiedy potrzeba. Według św. Tomasza cnota hojności nie jest zatem związana z miłością, ale raczej ze sprawiedliwością, gdyż ta odnosi się do rzeczy zewnętrznych (Tomasz z Akwinu 1972, q. 117, a. 5, ad. 3). Z punktu widzenia personalizmu można dzięki tej cnocie podkreślić wolność osoby wobec dóbr materialnych. Człowiek nieskończenie przewyższa je swoją wartością, dlatego winien unikać przywiązania do rzeczy. Wyraża to właśnie cnota hojności. Hojność to także ekscesywność w dowartościowaniu osoby swoimi dobrami materialnymi. Wprawdzie podstawą hojności nie jest obowiązek, czy nawet przyjaźń, ale według Akwinaty tworzy ją „pewna godziwość”. Osoba ludzka zawsze zasługuje na to, aby być wobec niej hojnym, oprócz sprawiedliwej zapłaty. Ma to podstawę w jej godności.

\section{Cnoty skierowane ku obronie wlasnej osoby w relacjach}

Oprócz wdzięczności należnej dobroczyńcom należy ustosunkować się także do osób wyrządzających krzywdę. Skoro według personalizmu ważnym wymiarem osoby jest relacyjność, oznacza to, że potrzebna jest cnota, która ma na celu przywrócić relację z krzywdzicielem, dzięki odbyciu przez niego należytej pokuty. Służy temu cnota vindicatio, co na język polski przełożono jako „pomsta” (Tomasz z Akwinu 1972, q. 108). Cnoty doskonalą człowieka, by postępował właściwie, idąc za naturalnymi skłonnościami, będącymi wyrazem prawa natury. $Z$ tego powodu każdej określonej skłonności naturalnej odpowiada odrębna cnota. W człowieku istnieje odrębna skłonność naturalna do usuwania rzeczy szkodliwych. Broni się on przed krzywdą oraz dokonuje pomsty za doznane już niesprawiedliwości, jednakże nie z zamiarem szkodzenia, lecz w celu usunięcia zła. Otóż zadaniem cnoty vindicatio jest odsuwanie przemocy, krzywdy i wszelkiej szkody przez samoobronę lub pomstę (Tomasz z Akwinu 1972, q. 108, a. 2). Podobnie jak wyrównanie należności prawnej jest zadaniem sprawiedliwości wymiennej, a wyrównanie należności moralnej, opartej na wyświadczeniu jakiegoś dobrodziejstwa, jest zadaniem cnoty wdzięczności, tak karanie za występki przeciw sprawiedliwości społecznej jest aktem sprawiedliwości wymiennej, karanie zaś 
za występki przeciw nietykalności prywatnej osoby (broniącej się przed krzywdą) jest zadaniem cnoty usprawniającej do właściwego sposobu pomsty (Tomasz z Akwinu 1972, q. 108, a. 2, ad. 1).

Jeśli mściciel zmierza głównie do wyrządzenia zła tej osobie i na tym poprzestaje, wówczas taka pomsta jest całkowicie niedozwolona jako przejaw nienawiści, sprzeciwiającej się miłości. Przy czym mściciela nie usprawiedliwia nawet to, że zmierza do zła jedynie dla tej osoby, która jemu niesprawiedliwie wyrządziła krzywdę albo go nienawidzi. Nie wolno bowiem grzeszyć przeciwko drugiemu człowiekowi z tego powodu, że on pierwszy zawinił, gdyż byłoby to zwycięstwem zła, przed czym przestrzega św. Paweł: „Nie daj się zwyciężyć złu, ale zło dobrem zwyciężaj” (Rz 12,21). Jeśli natomiast dokonujący pomsty zmierza do jakiegoś dobra przez ukaranie grzesznika, np. w celu poprawienia go albo przynajmniej do powstrzymania go od dalszych występków, do zapewnienia pokoju innym, zachowania sprawiedliwości lub chwały Bożej - wówczas pomsta może być dozwolona, jeśli są zachowane inne warunki dobrego uczynku (Tomasz z Akwinu 1972, q. 108, a. 1).

Akwinata rozstrzyga również zagadnienie uprawnień legalnej władzy do wymierzania kary. Kto stosownie do swego stanowiska dokonuje pomsty na złych ludziach, nie przywłaszcza sobie tego, co Boże, gdyż używa władzy zleconej mu przez Boga, według słów św. Pawła o władzy: „Jest ona narzędziem Boga do wyznaczenia sprawiedliwej kary temu, kto czyni źle" (Rz 13,4). Natomiast, kto wbrew porządkowi ustanowionemu przez Boga dokonuje pomsty, przywłaszcza sobie prawo Boże i dlatego grzeszy (Tomasz z Akwinu 1972, q. 108, a. 1, ad. 1). Tymczasem ludzie dobrzy winni cierpliwie znieść osobiste krzywdy, ale w miarę jak to jest godziwe. Nie mogą natomiast pozwolić na wyrządzanie krzywdy Bogu i bliźnim (Tomasz z Akwinu 1972, q. 108, a. 1, ad. 2).

Święty Tomasz dopuszcza także możliwość ukarania szerszej społeczności, jak to uczynił Bóg, gdy zniszczył całą Sodomę. Jeśli jednak występku dokonała nie cała społeczność, lecz tylko jej część, należy pomsty dokonać na sprawcach tego występku, jeśli da się ich oddzielić od ludzi niewinnych i jeśli jest możliwe dokonać tej pomsty bez wywołania zgorszenia innych. W przeciwnym razie należy wybaczyć społeczności i zaniechać surowości. To samo odnosi się do przywódcy społeczności. Należy znosić jego grzech, jeśli nie można go ukarać bez zgorszenia społeczności, z wyjątkiem jednak wypadku, gdy grzech tego naczelnika jest tak wielki, że wyrządziłby społeczności większą szkodę duchową lub doczesną niż zgorszenie wywołane przez ukaranie go (Tomasz z Akwinu 1972, q. 108 , a. 1, ad. 5).

Uznanie vindicatio za cnotę przez tradycję etyczną, zarówno pogańską, jak i tomistyczną, umożliwia wyciągnięcie dalszych wniosków w paradygmacie personalistycznym. Podkreśla ona wartość własnej osoby, konieczność miłowania samego siebie. By relacja interpersonalna była prawdziwa, potrzeba sprawiedli- 
wości wobec bliźniego, ale też wobec samego siebie. Cnota vindicatio umożliwia z jednej strony utrzymanie relacji, z drugiej strony obronę kogoś, komu grozi ciągłe bycie ofiarą. Wskazuje ona, że w ochronie siebie trzeba czegoś więcej niż wyrównania instrumentalnej sprawiedliwości (oko za oko, ząb za ząb). Akwinata nie poruszył w swoich rozważaniach wątku relacyjnego cnoty vindicatio, polegającego na tym, że po odbyciu właściwej pokuty osoba krzywdziciela staje się znowu przywrócona relacjom społecznym. Taka umiejętność włączenia winowajcy do wspólnoty jest rzeczywiście cnotą. O ile poprzednie cnoty były bezpośrednio afiliacyjne, vindicatio, jak również następna z omawianych cnót, czyli epikeia, wprowadza także właściwe granice w relacjach społecznych.

Ostatnią personalistyczną cnotą pokrewną sprawiedliwości, omawianą przez św. Tomasza, jest epikeia (Tomasz z Akwinu 1972, q. 120). Chroni ona osobę wobec prawa stanowionego, które dysponuje władzą nad człowiekiem, podobnie jak prawodawca. Relacja prawodawca-podwładny jest tu zapośredniczona, odbywa się poprzez prawo. Władza może okazać się przemocą, nie biorąc pod uwagę szczególnych okoliczności, w jakich może znaleźć się podwładny. Nikt nie jest w stanie ustanowić takich przepisów, które by w żadnym wypadku nie zawodziły. Toteż uchwalając je, prawodawcy biorą pod uwagę to, co ma miejsce zazwyczaj, chociaż w niektórych wypadkach przestrzeganie tych przepisów sprzeciwiałoby się sprawiedliwości i dobru ogółu, które jest celem prawa. Na przykład prawo stanowi, że należy oddać rzeczy dane do przechowania. Niekiedy jednak jest to szkodliwe, np. gdy ktoś żąda oddania depozytu, który pragnie użyć w celu szkodzenia innym ludziom. W takich wypadkach spełnienie przepisów prawa byłoby złe. Natomiast pomijające literę prawa, ale zgodne z duchem sprawiedliwości i pożytkiem ogółu, postępowanie jest w takich wypadkach dobre, jest ono zadaniem cnoty epikei (Tomasz z Akwinu 1972, q. 120, a. 1). Nie pomija ona tego, co zasadniczo jest sprawiedliwe, ale pomija przepis prawny. Nie przeciwstawia się także praworządności, która przestrzega prawdziwe ustawy wtedy, gdy trzeba. Natomiast przestrzeganie litery prawa wówczas, gdy nie należy, jest grzeszne (Tomasz z Akwinu 1972, q. 120, a. 1, ad. 1). Epikeia jest składnikiem sprawiedliwości w ogólnym znaczeniu tego wyrazu, jako jej gatunek, czyli jest jej składnikiem podmiotowym. W tym znaczeniu przysługuje jej pierwszeństwo przed sprawiedliwością społeczną, którą kieruje. Tak więc epikeia jest jakby wyższą normą postępowania ludzkiego (Tomasz z Akwinu 1972, q. 120, a. 2). W podejściu personalistycznym do tej cnoty należy podkreślić jej znaczenie w regulacji relacji prawo-osoba. Dzięki niej widać wyraźnie, że to osoba stoi wyżej w hierarchii wartości niż litera przepisu prawnego, które ma służyć jej prawdziwemu dobru. Osoba ludzka ma prawo bronić się przed usankcjonowaną prawnie niesprawiedliwością - takie jej zachowanie jest cnotliwe. 


\section{Zakończenie}

Cnoty pokrewne sprawiedliwości, opisane przez św. Tomasza, wyrażają stosunek osobowy człowieka do człowieka. W relacjach międzyludzkich nie wystarczy sama sprawiedliwość rozdzielcza, ale konieczne jest coś więcej: wdzięczność, cześć, uprzejmość, danie szansy na odpokutowanie swoich błędów. Przeciwieństwem takiego podejścia do drugiego człowieka jest relacja, w której jest on traktowany instrumentalnie, jest uprzedmiotowiony. Taki ukryty utylitaryzm łatwo może wkraść się w codzienne ludzkie relacje, w których szuka się przede wszystkim swojej korzyści. Rozdźwięk pomiędzy tym, na co osoba zasługuje, a tym co drugi człowiek może jej dać, wskazuje na istnienie Osoby doskonałej, w relacji z którą zaspokojone zostaną wszelkie potrzeby, wskazuje na istnienie Boga. Nasze ludzkie doświadczenie mówi bowiem raczej o ulotności ludzkiej wdzięczności, bezduszności przepisów prawa wobec ludzkich dramatów, hojności nie takiej, jak można by się spodziewać. Z drugiej strony można odkryć w ludzkim sercu nieustające pragnienie otrzymania i dawania ciągle czegoś więcej - rodzicom, dobroczyńcom, bliźnim, Ojczyźnie.

\section{THE VIRTUES RELATED WITH JUSTICE IN THE LIGHT OF THE PERSONALIST ETHICS}

\section{SUMMARY}

The virtues related to justice analyzed in the light of the personalist ethics indicate some features and rights of the human person, appertaining to them for the sake of their innate dignity. These virtues are: piety, respecting, honouring, obedience, generosity, friendliness, gratitude, truthfulness, vindication and epikeia. The humane person appears worthy of their acts, being the only creature on earth whom God willed for themselves.

Keywords: virtue, personalism, aretology, person

Słowa kluczowe: cnota, personalizm, aretologia, osoba 


\section{BIBLIOGRAFIA}

Arystoteles. 1996. Etyka nikomachejska. W: Arystoteles. Dzieła wszystkie, thum. Daniela Gromska, t. 5. 77-300. Warszawa: Wydawnictwo Naukowe PWN.

Barth, Grzegorz. 2008. Ku całościowej wizji osoby ludzkiej. Metodologiczne założenia personalizmu integralnego. Teologia $w$ Polsce, 2 (1), 43-53.

Burgos, Juan M. 2010. Personalizm. Autorzy i tematy nowej filozofii, thum. Krzysztof Koprowski. Warszawa: Centrum Myśli Jana Pawła II.

Burgos, Juan M. 2012. Personalizm dziś. Studia Włocławskie, 14, tłum. Witold Dorsz, 341-358.

Ćmiel, Henryk. 2008. Teologia moralna szczegółowa. Podręcznik dla studentów teologii. Częstochowa: Paulinianum.

Derdziuk, Andrzej. 2001. Aretologia w podręcznikach moralistów kapucyńskich. Lublin: RW KUL.

Derdziuk, Andrzej. 2019. Patriotyzm w czasie pokoju. Teologia i Moralność, 14 (1), 95-106. DOI: 10.14746/tim.2019.25.1.6.

Gerlaud, Marie-J. 1967. Cnoty społeczne. W: Wprowadzenie do zagadnień teologicznych. Teologia moralna. 876-915. Poznań-Warszawa-Lublin: Księgarnia Św. Wojciecha.

Guzowski, Krzysztof i Michał Kosche. 2016. Personalizm jako próba jednoczenia „zwaśnionych” antropologii. Horyzonty Polityki, 7 (2), 72-73.

Kant, Immanuel. 1984. Uzasadnienie metafizyki moralności, thum. Mścisław Wartenberg. Warszawa: PWN.

Seneka. 1965. O dobrodziejstwach. W: Seneka. Pisma Filozoficzne, thum. Leon Joachimowicz, 69-449. Warszawa: PAX.

Tomasz z Akwinu. 1970. Suma teologiczna. Sprawiedliwość, tłum. Feliks W. Bednarski, t. 18. Londyn: Katolicki Ośrodek Wydawniczy Veritas.

Tomasz z Akwinu. 1972. Suma teologiczna. Cnoty społeczne, thum. Feliks W. Bednarski, t. 20. Londyn: Katolicki Ośrodek Wydawniczy Veritas.

Wojtyła, Karol. 19864. Miłość i odpowiedzialność. Lublin: TN KUL.

Woroniecki, Jacek. 1986. Katolicka etyka wychowawcza, t. II/2. Lublin: RW KUL.

Krzysztof Niewiadomski OFMCap - kapłan, doktor teologii moralnej (UPJP II), mieszka i pracuje w Krakowie, mail: niewiadomski@kapucyni.pl 